\title{
RELATIONSHIP BETWEEN INTEGRATED MARKETING CAPABILITY ON SALES AND BRAND PERFORMANCE: MODERATION ROLES OF IMC PERFORMANCE
}

\author{
MOHAMADREZA HAMIDIZADEH \\ MOHSEN SANATI \\ ATEFEH GHOMI AVILI \\ Shahid Beheshti University of Iran
}

\begin{abstract}
Due to in the fierce competition in the fast moving consumers good (FMCG) industry and lack of growing demand in recent years in this industry, firms are now looking for more efficient and effective ways of creating value for their brands. In this regard, integrated marketing communication (IMC) is a newly introduced concept which has not been thoroughly investigated in the FMCG market of Iran. Therefore, the aims of this study are twofold, first, is to empirically examine the influence of IMC capability of the organization on the brand and sales performance. Second, is the investigation of the moderation role of the IMC performance which is not covered in the literature. The detergent industry was investigated by choosing one of the biggest detergent players in Iran, and the sample of brand, advertising and marketing managers, and experts were considered for distribution of the questionnaire. The results support the effect of IMC capability on sales and brand performance. Moreover, the analysis showed support for moderation role of IMC performance. Managerial implications are discussed at the last section of this research.
\end{abstract}

Keywords: IMC capability, IMC performance, Brand performance, Sales performance

\section{Introduction}

Iran recorded a real GDP decline in both 2012 and 2013, coupled with high inflation. This decline decreased household budgets in these years and resulted in a volume sales decline for many areas. A return to real GDP growth and lower inflation in 2014 meanwhile resulted in stronger economic confidence, boosting sales growth for many product areas including detergents. However, the majority of consumers continue to struggle financially, with many using laundry detergents and bleach for a wide range of home-cleaning chores. Many product areas such as surface care, toilet care and polishes thus continue to see fairly low sales levels (Euromonitor International, 2014).

Low sales levels coupled with growth of competition due to increasing numbers of rivals in recent years has led the detergent industry to be stagnant and the evidence of this is the stable rate of demand in 2013 and 2014 which is shown in the table below:

Table 1

Detergent Industry Market Size

\begin{tabular}{lllllll}
\hline IRR billion & 2009 & 2010 & 2011 & 2012 & 2013 & 2014 \\
\hline Detergent & 12373 & 14435 & 20806 & 31261 & 42889 & 43897 \\
\hline
\end{tabular}

Source: Euromonitor international from official statistics, trade associations, trade press, company research, store checks, trade interview, trade sources 
Stable demand will lead to a stable market size in the detergent industry. However an increased number of competitors in recent years has led to fierce competition. Therefore, companies in the detergent industry are forced to evaluate their marketing capabilities and shift their marketing strategies to be adapted to the maturity life cycle of the industry.

The main aim of this paper is to examine the marketing capabilities and specially marketing integrated communication. Since the early 2000s, integrated marketing communication (IMC) has become the major concern in the marketing communications field (Kitchen, Joanne, \& Tao. 2014; Lee \& Park, 2007). Marketing communication plays an important role in building relationships and leveraging these relationships in terms of brand equity (Dawar, 2004). Marketing executives now consider IMC as a key competitive advantage associated with marketing (Lee \& Park, 2007). Despite such a wide acceptance, many issues in integrated marketing communication remain to be resolved. For example how IMC could affect sales and brand performance and the role of IMC in the equation.

The influence of IMC on the current marketing communication cannot be determined without considering the role of IMC performance in the equation. Therefore, the aim of this study is twofold. First, with use of relevant literature review a conceptual model will be discussed and operationalized to examine the relation of IMC with sales performance and brand performance. Second, it will examine the moderation role of IMC performance on the relation of IMC and sales performance and brand performance.

\section{Literature Review}

Since the early 2000s, initial attempts have been made to define the concept of IMC. Now literature has an abundance of definitions (Kliatchko, 2005; Tao, 2004). IMC is defined as "a process for managing the customer relationship that drives brand value. More specifically, it is a cross-functional process for creating and nourishing profitable relationships with customers and other stakeholders by strategically controlling or influencing all messages sent to these groups and encouraging data driven, purposeful dialogue with them" (Duncan, 2012). Despite the comprehensive definition of Duncan, following researchers showed that IMC should be more strategic than executional, more than being simple sales and promotion messages, including two way communications and being result driven (Reid, Luxton \& Mavondo, 2005). These findings led to a more comprehensive definition of this term and in the following paper in 2004 Dunan and Mulhern redefined this concept as "an ongoing, interactive, cross functional process of brand communication planning, execution, and evaluation that integrates all parties in the exchange process in order to maximize mutual satisfaction of each other's want and needs" (Duncan \& Mulhern, 2014).

Philosophical look has emphasised raising the awareness of the benefit of IMC and managers intention to integrate communication messages. IMC is evolving as a strategic management process which by the integration of activities in a cross boundary manner employs the knowledge and skills of the related managers to integrate all responsibilities for communication (Ratnatunga \& Evwing, 2015). By emphasising the effective and efficient relationship with customers and stakeholders, IMC boosts perceptions about the brand. Therefore, IMC plays an important role to gain market advantage by using of improving the brand (Luxton, 2015).

Integrated marketing communication capability has several associated benefits including helping companies to focus on their financial resources, and allocate it to their customers with the deployment of outside-in method of thinking (e.g. starts from customers). It is intended to pool all the elements of marketing and communication into a valuable and measurable process that is evaluable regarding effectiveness and efficiency. It consequently motivates coordination of all the company's communication activities into a whole via a common firm-wide framework. Finally, it facilitates the effective use of external resources and internal capabilities to achieve maximum results (Ratnatunga \& Ewing, 2015). 
According to the definition of Luxton, IMC capability is "Cohesive coordination of all the firm's communication activities into a whole via a common firm-wide framework to facilitate the effective use of external resources and internal capabilities to achieve maximum results" (Luxton, 2015).

\section{IMC capability and brand performance}

In the face of many challenges in the business environment, brands are gaining increasing value due to perceived credibility and trustworthiness of the firm. In the other words, brand is a bridge by which companies' value proposition will be conducted to the customer which will finally result in emotional attachment, purchase and loyalty (Rust, Ambler, Carpenter, Kumar \& Srivastava, 2004). Conducting marketing communication strategies and maintenance of long-term brand value is an important aspect of building strong brands (Ambler, 2013).

Regarding IMC capabilities impact on market performance, Luxton, (2015) researched the impact of IMC capability on brand market performance and brand financial performance. In the sample of Australian brand managers he investigated how IMC capability is related to campaign effectiveness and how this capability can affect brand financial performance (sales performance) with mediation of brand market performance. The results showed that IMC capability has a direct effect on brand market performance and also the hypothesis of the effect of IMC capability on brand financial performance through brand market performance found support (Luxton, 2015).

There are other researches in the literature regarding the examination of IMC on market performance and sales performance. For example, in one research, the effect of IMC performance was examined on market performance. In this research, market performance had dimensions of brand advantage, customer satisfaction and sales performance. The results showed that IMC performance has a direct effect on market performance (Rien, 2005). Moreover, in another research, the effect of the components of IMC was examined on immediate and future sales through the mediation role of brand recognition capability (Ratnatunga \& Ewing, 2015).

Based on prior research in literature we can conclude that:

H1 : IMC capability has a direct positive effect on sales performance.

\section{IMC capability and brand performance}

IMC is main consequence was on creating value for brand which would lead to improvement of brand performance. In this regard we have several researches in literature. In one research, the effect of IMC performance was investigated on brand advantage. This study was performed in the United States on both the goods and services industries. The results support the effect of IMC performance on brand advantage in both industries (Ried, 2005).

Regarding effect of IMC on brand equity several studies have been conducted On the them is the research of Madhavaram, Badrinarayanan and Mcdonal in which a conceptual model for the effect of IMC on brand equity was proposed. In the model IMC was considered as a brand equity contact factor which had an effect on brand equity. The results showed that IMC has a direct positive effect on brand equity (Madhavaram, Badrinarayanan \& Mcdonal, 2013). Finally a research showed that brand orientation and market orientation have direct positive effects on IMC and IMC has a direct positive effect on brand performance (Ried, Luxton \& Mavondo, 2005).

Prior researches in the literature mostly had a perspective of the IMC from the firm is side; in one research there was an examination of the IMC perception from the perspective of a customer. In this research they concluded that IMC perception has direct positive effect on Brand image, perceived quality and brand loyalty. Brand loyalty would consequently lead to more repurchase of the brand (Seric, 2014). Based on prior researches and the study of literature, we can conclude that: 
$H 2$

IMC capability has a direct positive effect on brand performance.

\section{Moderation role of IMC performance}

Although we have a myriad of research in the realm of IMC, there are limited researches concerning the performance of IMC and the relation of IMC performance with other related concepts related to brand and sales performance. In one research, IMC performance was considered as a multi-dimensional construct from cross-functional strategic planning, interactivity and mission marketing. In the mentioned research the impact of IMC performance was investigated an market performance which was composed of brand advantage, customer satisfaction and sales performance. The results support the impact of IMC performance on market performance (Reid, 2005).

There are a few studies related to how IMC affects marketing performance. In the research of Syhputra (2013), the relationship between integrated marketing communication management and marketing performance was studied on medium enterprises in Malaysia. In this research IMC as a multi-dimension construct included interactivity, mission marketing, organizational infrastructure, strategic consistency and planning, and evaluation On the other side, marketing performance was studied by sales-related performance, brand advantage and customer satisfaction. The results showed that IMC management had an effect on marketing performance (Syhputra, 2013).
In the realm of business - to - business marketing there is an examination of IMC effectiveness. For example, in the study of Jerman and Zavrsnik (2012), building on related literature in the business - to - business realm, the model tested the impact of marketing communication objectives, communication channels and bidirectional communication of IMC effectiveness and organization performance. The results showed that IMC effectiveness has a direct effect on organizational performance (Jernam \& Zavrsnik, 2012).

Based on the review of the prior researches one can see that there are a few researches evaluating antecedents and consequences of IMC performance and to the best knowledge of the researcher there is no research considering the moderator role of this concept. Since the relation of IMC capability and IMC performance is supported (Reid, 2005) and IMC capability has a relationship with brand value (Luxton, 2015; Reid, 2005), we can hypnotize that:

\section{H3 : IMC performance has a moderation effect on the relationship between IMC capability and sales performance. \\ H4 : IMC performance has a moderation effect on the relationship between IMC capability and brand performance.}

Based on the literature and the developed hypotheses the conceptual model below was developed:

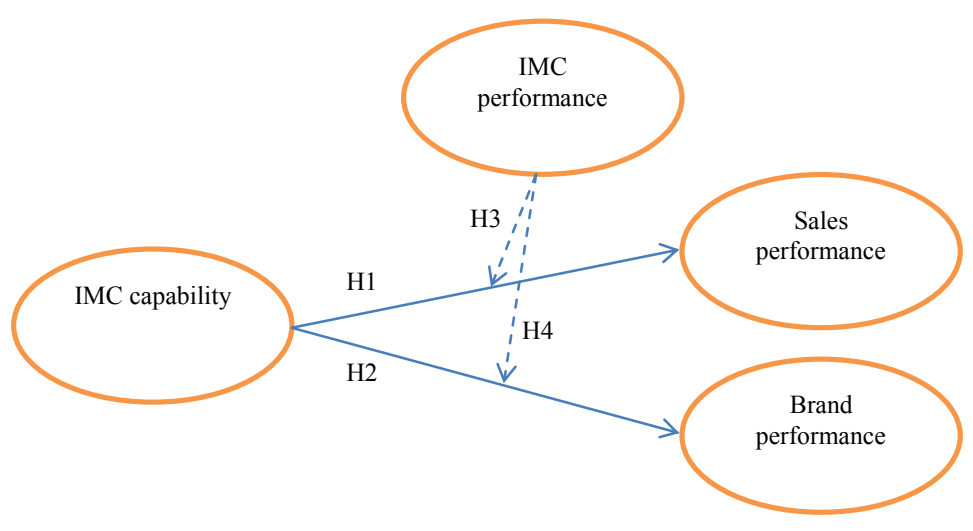

Figure 1. Conceptual model 


\section{Research Methodology}

\section{Sample}

The data for this research were gathered using a self-administrated questionnaire. The population was all the brand marketing and advertising managers and experts of Golrang Industrial Group (GIG) active in the detergent industry. Because GIG has different companies for production and distribution and also not all the brands related to detergent belong to one company, the questionnaires were distributed among all the related companies.

The population consisted of 215 managers of brands, marketing, advertising and experts of detergent related brands. According to the Morgan table the sample should be at least 136. Considering the response rate via self-administrated questionnaires, 150 questionnaires were distributed, however, 139 usable questionnaires were returned. The general information of the sample is presented in Table 2.

Table2

Demographic Information of the Sample

\begin{tabular}{lcc}
\hline \multirow{2}{*}{$\begin{array}{l}\text { a)Manager } \\
\text { b)Expert }\end{array}$} & Position & $\begin{array}{c}\text { Percentage } \\
28\end{array}$ \\
\hline \multirow{2}{*}{ a)Married } & Marital Status & 72 \\
b)Single & & 28 \\
\hline \multirow{2}{*}{ a)Under 30 } & Age & 25 \\
b)30-40 & & 34 \\
c)41-50 & & 28 \\
d)More than 50 & & 13 \\
\hline \multirow{2}{*}{ a)Man } & Gender & 62 \\
b)Woman & & 38 \\
\hline & & \\
a)Diploma & Education & 10 \\
b)Bachelor & & 68 \\
c)Master's or higher & & 22 \\
\hline
\end{tabular}

As Table 2 shows, $62 \%$ of the sample were men and the rest were women. Most of the participants had bachelor degrees and there were a few people with diplomas (10\%). The majority of the participants were between 30 to 40 years old and $72 \%$ were married.

\section{Measures}

This study has used scales to capture the data on IMC capability, IMC performance, sales performance and brand performance. IMC performance was adapted from the scale of
Duncan and Moriarty. The IMC capability construct was composed of 12 questions based on measures used in previous IMC researches to examine how well a firm is able to undertake marketing communication activities. The sales performance scale was adopted from the research of Reid (2005). For the questions on brand performance, the scale of Ried (2005) was adopted. All items were measured on a 5-point Likert scales where 1 was for strongly disagree and 7 for strongly agree. For scales of sales and brand performance 1 indicated 
"much less" and 5 indicated "much more". After evaluating the questionnaire with a small sample of managers and academics the phrasing of the items was modified to improve the managers' understanding of the concepts. Other items in the questionnaire were demographic questions regarding age, gender, education and position in the company.

\section{Analysis}

\section{Confirmatory measurement model}

In order to perform statistical analysis LISREL 8.5 and SPSS 21 were used as statistical software. As shown in Table 3, a confirmatory factor analysis was first performed for testing the variables. Moreover, the reliability of scales was measured through composite reliability and Cronbach's alpha for all the constructs. In particular, all the estimated indices were above the threshold of 0.7 for Cronbach's alpha (Nunnally \& Bernstein, 1994) and 0.6 for CR
(Bagozzi, 1988). This showed good internal consistency of scales. In addition, the findings obtained acceptable values for the extracted variances, all the standardized factor loadings being statistically significant for all the items except one item which had been removed. Moreover, as all average variance extracte values were greater than 0.5 , we concluded that more than $50 \%$ of the variances of a construct was due to its indicators (Fornell \& Larcker, 1981). All these allowed us to confirm the convergent validity of the model.

In order to test discriminant validity, we used Fornell and Larcker's (1981) criterion, since it is considered as the most stringent one (Farrell, 2010). This method requires a construct's extracted variance to be bigger than the squared correlation of this construct with another construct. As depicted in Table 4, all the square roots of AVE were higher than the correlation between the constructs. Therefore, the discriminant validity was also confirmed.

Table 3

Constructs and Items Measurements

\begin{tabular}{|c|c|c|c|c|c|c|}
\hline Construct & Item & $\begin{array}{l}\text { St. } \\
\text { loading } \\
\text { factor }\end{array}$ & $\mathrm{T}$ & $\begin{array}{l}\text { Cronbach's } \\
\text { alpha }\end{array}$ & $\begin{array}{l}\text { Composite } \\
\text { reliability }\end{array}$ & $\begin{array}{l}\text { Average } \\
\text { variance } \\
\text { extracted }\end{array}$ \\
\hline \multirow[t]{6}{*}{$\begin{array}{l}\text { IMC } \\
\text { capability }\end{array}$} & $\begin{array}{l}\text { All of our marketing communication tools } \\
\text { work together to achieve our overall brand } \\
\text { communication goals. }\end{array}$ & - & 3.0 & 0.72 & 0.93 & 0.68 \\
\hline & $\begin{array}{l}\text { Our creative theme is broad enough to } \\
\text { be used in campaigns aimed at different } \\
\text { stakeholder groups. }\end{array}$ & 0.78 & 10.7 & & & \\
\hline & $\begin{array}{l}\text { We regularly discuss our brand's } \\
\text { communication strategy with our creative } \\
\text { agencies. }\end{array}$ & 0.65 & 9.9 & & & \\
\hline & $\begin{array}{l}\text { We coordinate all our external agencies so } \\
\text { they know one another's roles in achieving } \\
\text { our brand communication. }\end{array}$ & 0.79 & 7.0 & & & \\
\hline & $\begin{array}{l}\text { Our marketing communication strategy } \\
\text { is driven by clear objectives for creating } \\
\text { relationships with key stakeholders. }\end{array}$ & 0.63 & 4.5 & & & \\
\hline & $\begin{array}{l}\text { Target market insights from market } \\
\text { research guide our campaign planning } \\
\text { process. }\end{array}$ & 0.60 & 4.5 & & & \\
\hline
\end{tabular}




\begin{tabular}{|c|c|c|c|c|c|c|}
\hline Construct & Item & $\begin{array}{l}\text { St. } \\
\text { loading } \\
\text { factor }\end{array}$ & $\mathrm{T}$ & $\begin{array}{l}\text { Cronbach's } \\
\text { alpha }\end{array}$ & $\begin{array}{l}\text { Composite } \\
\text { reliability }\end{array}$ & $\begin{array}{l}\text { Average } \\
\text { variance } \\
\text { extracted }\end{array}$ \\
\hline & $\begin{array}{l}\text { We conduct a SWOT analysis to help } \\
\text { determine our brand's marketing } \\
\text { communication planning. }\end{array}$ & 0.57 & 5.6 & & & \\
\hline & $\begin{array}{l}\text { Our brand communication strategies } \\
\text { maximize the strengths of all marketing } \\
\text { communication tools. }\end{array}$ & 0.83 & 6.0 & & & \\
\hline & $\begin{array}{l}\text { A clear understanding of all our "brand } \\
\text { touch points" guides our campaign } \\
\text { planning process. }\end{array}$ & 0.67 & 8.7 & & & \\
\hline & $\begin{array}{l}\text { We thoroughly evaluate the performance } \\
\text { of every campaign. }\end{array}$ & 0.57 & 7.1 & & & \\
\hline & $\begin{array}{l}\text { Our business commits us to maintain } \\
\text { highly skilled personnel to manage our } \\
\text { brand communications. }\end{array}$ & 0.61 & 9.0 & & & \\
\hline & $\begin{array}{l}\text { Adequate time is made available to plan } \\
\text { and execute brand communications. }\end{array}$ & 0.62 & 5.8 & & & \\
\hline \multirow[t]{9}{*}{$\begin{array}{l}\text { IMC } \\
\text { performance }\end{array}$} & $\begin{array}{l}\text { Our brand's media plan is a strategic } \\
\text { balance between mass media and one - to } \\
\text { - one media. }\end{array}$ & 0.71 & - & 0.84 & 0.88 & 0.62 \\
\hline & $\begin{array}{l}\text { Special programs are in place to facilitate } \\
\text { customer inquiries and complaints about } \\
\text { our brand. }\end{array}$ & 0.62 & 10.5 & & & \\
\hline & $\begin{array}{l}\text { In our database we capture customer } \\
\text { inquiries, complaints, compliments, and } \\
\text { sales behavior related to our brand. }\end{array}$ & 0.69 & 6.8 & & & \\
\hline & $\begin{array}{l}\text { Our companies mission statement is a } \\
\text { key consideration in the communications } \\
\text { planning for our brand. }\end{array}$ & 0.78 & 6.8 & & & \\
\hline & $\begin{array}{l}\text { Our mission statement is promoted among } \\
\text { customers and other key stakeholders of } \\
\text { our brand. }\end{array}$ & 0.68 & 10.4 & & & \\
\hline & $\begin{array}{l}\text { In our company the process of managing } \\
\text { the brand's reputation is the responsibility } \\
\text { of all departments and employees. }\end{array}$ & 0.66 & 4.7 & & & \\
\hline & $\begin{array}{l}\text { The people managing the communications } \\
\text { program for our brand have a good } \\
\text { understanding of the strengths and } \\
\text { weaknesses of all major marketing } \\
\text { communications tools such as direct } \\
\text { response, PR, sales promotion, advertising, } \\
\text { and packaging. }\end{array}$ & 0.68 & 4.0 & & & \\
\hline & $\begin{array}{l}\text { Our company does a good job of internal } \\
\text { marketing, informing all areas of the } \\
\text { organization about our brand's objectives } \\
\text { and marketing programs. }\end{array}$ & 0.60 & 5.2 & & & \\
\hline & $\begin{array}{l}\text { Our major communication agencies have } \\
\text { monthly contact with each other regarding } \\
\text { our brand. }\end{array}$ & 0.77 & 8.6 & & & \\
\hline
\end{tabular}




\begin{tabular}{|c|c|c|c|c|c|c|}
\hline Construct & Item & $\begin{array}{l}\text { St. } \\
\text { loading } \\
\text { factor }\end{array}$ & $\mathrm{T}$ & $\begin{array}{l}\text { Cronbach's } \\
\text { alpha }\end{array}$ & $\begin{array}{l}\text { Composite } \\
\text { reliability }\end{array}$ & $\begin{array}{l}\text { Average } \\
\text { variance } \\
\text { extracted }\end{array}$ \\
\hline & $\begin{array}{l}\text { We regularly review our marketing plan } \\
\text { to ensure the relevance and consistency } \\
\text { of our brand messages and strategic brand } \\
\text { positioning. }\end{array}$ & 0.40 & 5.7 & & & \\
\hline & $\begin{array}{l}\text { We carefully coordinate the messages } \\
\text { being sent by all of our operations, } \\
\text { such as pricing, distribution, product } \\
\text { performance, and service operations to } \\
\text { ensure consistency of brand positioning. }\end{array}$ & 0.71 & 6.4 & & & \\
\hline & $\begin{array}{l}\text { We use a fresh start or zero-based approach } \\
\text { in planning our brand's marketing } \\
\text { communication rather than using last } \\
\text { year's budget allocations. }\end{array}$ & 0.63 & 4.4 & & & \\
\hline & $\begin{array}{l}\text { We use some type of systematic brand } \\
\text { tracking study to evaluate the strength of } \\
\text { our relationships with customers and other } \\
\text { key stakeholder groups. }\end{array}$ & 0.68 & 4.7 & & & \\
\hline & $\begin{array}{l}\text { Our brand marketing strategies maximize } \\
\text { the unique strengths of the various } \\
\text { marketing communications tools. }\end{array}$ & 0.68 & 7.6 & & & \\
\hline \multirow[t]{3}{*}{$\begin{array}{l}\text { Sales } \\
\text { performance }\end{array}$} & $\begin{array}{l}\text { What is your market share compared to } \\
\text { your closest competitor? }\end{array}$ & 0.76 & - & 0.73 & 0.93 & 0.67 \\
\hline & $\begin{array}{l}\text { What is your sales growth compared to } \\
\text { your closest competitor? }\end{array}$ & 0.80 & 5.6 & & & \\
\hline & $\begin{array}{l}\text { What is your total sales income compared } \\
\text { to your closest competitor? }\end{array}$ & 0.65 & 6.4 & & & \\
\hline \multirow[t]{3}{*}{$\begin{array}{l}\text { Brand } \\
\text { performance }\end{array}$} & $\begin{array}{l}\text { What is your customers' level of brand } \\
\text { awareness compared with your closest } \\
\text { competitor? }\end{array}$ & 0.80 & - & 0.81 & 0.93 & 0.62 \\
\hline & $\begin{array}{l}\text { What is your ability to command premium } \\
\text { prices over similar competing brands in } \\
\text { your principal market? }\end{array}$ & 0.75 & 9.6 & & & \\
\hline & $\begin{array}{l}\text { What level of channel cooperation do } \\
\text { you receive relative to similar competing } \\
\text { brands in your principal market? }\end{array}$ & 0.82 & 9.2 & & & \\
\hline
\end{tabular}

Table 4

Means, Standard Deviation, Square Root of AVE and Correlations between Constructs

\begin{tabular}{lcccccc}
\hline \multirow{2}{*}{ Construct } & Mean & Std. deviation & \multicolumn{4}{c}{ Correlations } \\
\cline { 4 - 7 } & & & $\begin{array}{c}\text { IMC } \\
\text { capability }\end{array}$ & $\begin{array}{c}\text { IMC } \\
\text { performance }\end{array}$ & $\begin{array}{c}\text { Sales } \\
\text { performance }\end{array}$ & $\begin{array}{c}\text { Brand } \\
\text { performance }\end{array}$ \\
\hline IMC capability & 3.92 & 0.89 & 0.82 & - & - & - \\
$\quad$ IMC performance & 4.01 & 0.76 & 0.45 & 0.79 & - & - \\
Sales performance & 3.68 & 1.06 & 0.59 & 0.39 & 0.82 & - \\
Brand performance & 3.72 & 0.95 & 0.63 & 0.74 & 0.62 & 0.78 \\
\hline
\end{tabular}

Note: diagonal numbers are square root of average variance extracted and others are correlations 


\section{Hypothesis Tests}

Once we had verified the reliability and validity of the measurement scales, we estimated the structural equation model for the total sample. As presented in Table 5, the goodness of fit statistics showed that the model reasonably fits the data. The overall fit of the model appeared to be acceptable with chi-square, CFI, IFI, BentlerBonett NNFI, and RMSEA of 314.5, .944, 0.913, 0.911 , and 0.063 , respectively. Furthermore, the results of the multivariate test of the structural equations indicated that as a whole the model explained $65.4 \%$ of the variance of the sales performance. The explained variance for brand performance was $54.3 \%$.

Regarding the relationships between IMC capability, sales performance and brand performance we found support for the hypotheses. In particular, positive and significant relationships were corroborated between IMC capability and sales performance $(\beta=0.45, \quad p<0.05)$, and brand performance $(\beta=0.52, \mathrm{p}<0.05)$; thus supporting $\mathrm{H} 1$ and $\mathrm{H} 2$.
A multisample analysis was performed to test the moderating role of IMC performance, after dividing the total sample into two groups, depending on IMC performance. In order to obtain a similar number of participants in these two groups, the median value of IMC performance was considered as a reference, since the median is defined as the value having half of the observations less than and half exceeding it. The average value of the items measuring IMC performance provided a median value of 3.00. Thus, low IMC performance participants are those that have an average assessment above the level of IMC performance below the median value (3.00), whereas high IMC performance participants are those showing an average IMC performance score about the median.

The results showed that the relationships between IMC capability and brand sales are stronger for participants with higher IMC perception, compared to those with lower levels of IMC performance. The difference between low and high IMC performances were significant and therefore, hypotheses $\mathrm{H} 3$ and $\mathrm{H} 4$ are supported.

Table 5

Structural Equations Model Results: Multi-Sample Analysis

\begin{tabular}{|c|c|c|c|c|c|c|c|}
\hline \multirow[t]{2}{*}{ relationship } & \multicolumn{2}{|c|}{$\begin{array}{l}\text { Low IMC performance } \\
(\mathrm{N}=71)\end{array}$} & \multicolumn{2}{|c|}{$\begin{array}{c}\text { High IMC } \\
\text { performance }(\mathrm{N}=68)\end{array}$} & \multirow[t]{2}{*}{$\begin{array}{c}\mathrm{Chi}^{2} \\
\text { difference }\end{array}$} & \multirow[t]{2}{*}{ p-value } & \multirow[t]{2}{*}{ Hypothesis } \\
\hline & $\begin{array}{c}\text { St. } \\
\text { parameter }\end{array}$ & p-value & $\begin{array}{c}\text { St. } \\
\text { parameter }\end{array}$ & p-value & & & \\
\hline $\begin{array}{l}\text { IMC capability } \rightarrow \text { sales } \\
\text { performance }\end{array}$ & 0.311 & 0.000 & 0.548 & 0.000 & 0.188 & 0.011 & H3 supported \\
\hline $\begin{array}{l}\text { IMC capability } \rightarrow \text { brand } \\
\text { performance }\end{array}$ & 0.212 & 0.000 & 0.515 & 0.000 & 0.365 & 0.005 & H4 supported \\
\hline
\end{tabular}

\section{Discussion and Implications}

The findings of this study confirm positive and significant relationships between IMC capability on sales and brand performances. Further, the study confirms the moderating effect of IMC performance on the relationship between IMC capability and sales and brand performances. The findings contribute to the theory and practice in several major ways.
First, the research represents one of the few first efforts to empirically assess IMC performance as a moderator analysis. While IMC capability and other brand building activities may be important contributors to sales improvement, supporting this with empirical evidence was difficult (Stewart, 2009). The findings of this study shows that IMC capability contributes to sales and brand performance. Considering the items in the questionnaire, this contribution is mostly 
due to the development and implementation of more effective IMC campaigns resulting in positive brand-related market performance outcomes. Brand and marketing managers should be cautious about the allocation of enough resources for building IMC capability, ensuring that sufficient financial and human investment underpin the firm's ability to design and execute campaigns over time.

Another implication of this study is the role of IMC performance on better performance of sales and brand in the market. In other words, IMC capability alone is not enough and the firm needs high performance of IMC to be assured of the final result on sales and brand.

Since the industry of study in this research was detergent, we can conclude that based on empirical results, firms should first assess their IMC capability and IMC performance before devoting huge amounts of funds and budget on campaigns. Firms can invest to improve their IMC performance by integrating all the components of this concept and track the shortcomings, which will lead to huge savings on the budget for campaigns. This chain of IMC performance links firm processes and activities in marketing communication management and campaigns with customer and brand equity outcomes and financial outcomes; similar to the brand value chain concept (Keller \& Lehmann, 2006). Therefore, firms should be concerned about building strategic IMC capabilities. Finally, with the development of a comprehensive metrics for IMC performance, firms could manage to track all the processes of IMC and highlight bottlenecks which by improving those firms can be assured of both savings on the campaign budget and improvement of sales and brand performance.

Integrated marketing communication has been considered as a unique concept. Future researches can emphasise on different aspects of IMC like package, place, and promotion communication. This will make clearer exactly what part of communication affects sales and brand performance more. The industry under investigation in this research was fast moving consumer industry good. Future research can conduct similar research in different fields particularly service industries like banking and financial institutes. One limitation of this study was the lack of conciseness of the managers and experts with marketing concepts which forced the authors to first conduct training sessions for them and make them ready to cooperate in answering the questions. Data gathering was done using a questionnaire which has its own down sides like lack of cooperation in some departments.

\section{References}

Ambler, T. (2013). Marketing and the bottom line: The marketing metrics to pump up cash flow. London: Prentice Hall.

Bagozzi, R. P. (1988) On the evaluation of structural equation models. Journal of the Academy of Marketing Science, 16(1), 74-94.

Cornelissen, J., \& Lock, A. (2010). Theoretical concept or management fashion? Examining the significance of IMC. Journal of Advertising Research, 40(5), 7-15.

Dawar, N. (2004). What are brands good for? MIT Sloan Management Review, 46(1), 31-37.

Duncan, T. (2012). IMC: Using advertising and promotion to build brands. New York: McGraw-Hill.

Duncan, T., \& Moriarty. (2007). Driving brand value, New York: McGraw Hill.

Duncan, T., \& Mulhern, F. (2014). A white paper on the status, Scope and future of IMC (from IMC symposium sponsored by the IMC programs at Northwestern University and the University of Denver). New York: McGraw-Hill.

Fornell, C., Larcker, F. (1981). Evaluating structural equation models and unobservable variables and measurement error. Journal of Marketing Research, 18(1), 39-50.

Jerman, D., \& Zavrsnik, B. (2012). Model of marketing communication effectiveness 
in the business to business markets. Economic Research, 25(1).

Keller, K., L., \& Lehmann, D. (2003). How do brands create value? Marketing Management, 12(3), 26-32.

Kitchen, P. J., Joanne, B., \& Tao, L. (2014). The emergence of IMC: A theoretical perspective. Journal of Advertising Research, 44(1), 19-30.

Kliatchko, J. (2005). Towards a definition of integrated marketing communications (IMC). International Journal of Advertising Research, 24(1), 7-34.

Lee, D. H., \& Park, C. W. (2007). Conceptualization and measurement of multidimensionality of integrated marketing communications. Journal of Advertising Research.

Luxton, S. (year). Integrated marketing communication capability and brand performance. Journal of Advertising, 44(1), 37-46.

Madhavaram, S., Badrinarayanan, V., \& Mcdonal, R., E. (2013). Integrated marketing communication (IMC) and brand identity as critical components of brand equity strategy. Journal of Advertising, 34(4).

Nunnally, J. C., \& Bernstien, I. H. (1994). Psychometric theory ( $3^{\text {rd }}$ ed.). McGraw Hill, New York.

Ried, M. (2005). Performance auditing of IMC actions and outcomes. Journal of Advertising, 34(4), 41-52.

Ratnatunga, J., \& Ewing, M. (2015). The brand capability value of integrated marketing communication (IMC). Journal of Advertising, 34(4), 41-52.

Reid, M., Luxton, S., \& Mavondo, F. (2005). The relationship between IMC and its antecedents: Marketing orientation and brand orientation. Journal of Advertising, 34(4), 11-24.

Rust, R., Ambler, T., Carpenter, S., Kumar, Vl ?, \& Srivastava, K. (2004). Measuring marketing productivity: Current knowledge and future directions Journal of Marketing, 68(4), 76-89.

Stewart, D. W. (2009). Market-back approach to the design of integrated communications programs: A change in paradigm and a focus on determinants of success. Journal of Business Research, 37(3), 147-53.

Syhputran. (2013). Relationship between integrated marketing communications management and marketing performance of small medium enterprise in Malaysia. International Journal of Science and Research, 6(14).

Seric, M., Gil-Saura, I., Eugenia, M., \& Molina, R. (2014). How can integrated marketing communications and advanced technology influence the creation of customer-based brand equity? Evidenc from the hospitality industry. International Journal of Hospitality Management, 39, 144-156.

Tao, L. (2004). The emergence of IMC: A theoretical perspective. Journal of Advertising Research, 44(1), 19-30. 